\title{
Isolated basal ganglia hemorrhage due to blast injury
}

\author{
Blastik yaralanmaya bağlı izole bilateral bazal ganglion kanaması
}

\section{Fuldem Mutlu AYGÜN, ${ }^{1}$ Murat Serhat AYGÜN, ${ }^{2}$ Mehmet Bülent ÖNAL, ${ }^{3}$ Osman Lütfi DEMİRCI ${ }^{4}$}

\begin{abstract}
Bilateral traumatic hemorrhage of the basal ganglia is an extremely rare neuropathologic entity. Bilateral basal ganglia hemorrhage secondary to blast injury has not described before. We report a case with bilateral basal ganglia hemorrhage secondary to explotion.
\end{abstract}

Key Words: Basal ganglia; hemorrhage; trauma.
Bilateral travmatik bazal ganglion kanaması son derece nadir bir nöropatolojik antitedir. Blastik yaralanmaya bağlı bilateral bazal ganglion kanaması daha öncesinde hiç tanımlanmamıştı. Patlamaya bağlı gelişmiş bilateral bazal ganglion kanaması olan bir olgu sunuldu.

Anahtar Sözcükler: Basal ganglion; kanama; travma.
Bilateral basal ganglia hemorrhages are extremely rare and generally occur due to hypertension. ${ }^{[1]}$ There are some reports about bilateral basal ganglia hemorrhage etiologies like lightening ${ }^{[2]}$ diabetic ketoacidosis, ${ }^{[3]}$ and alcohol and cocaine intoxication, ${ }^{[4]}$ but only a few articles about trauma. ${ }^{[5,6]}$

We report herein a case of bilateral basal ganglia hemorrhage due to blast injury.

\section{CASE REPORT}

A 35-year-old man was admitted to our clinic after injury due to a rocket explosion. Neurological examination revealed that the patient was comatose, and the physical examination revealed only a mild scalp laceration. Chest radiography, electrocardiogram, and blood pressure were all normal.

Non-contrast computed tomography (CT) was performed, and revealed bilateral basal ganglia hemorrhage with peripheral edema (Fig. 1), without any signs of subdural or subarachnoid bleeding.
Conservative treatment was carried out, and the patient was discharged about seven days later without any deficit.

\section{DISCUSSION}

Blast injuries are divided into four classes: primary, secondary, tertiary, and quaternary. Primary injuries are caused by blast overpressure waves or shock waves. These are especially likely when a person is close to an explosion. The extent and types of primary blast-induced injuries depend on the peak of the overpressure, number of overpressure peaks, time lag between overpressure peaks, characteristics of the shear fronts between overpressure peaks, frequency resonance, and electromagnetic pulse. Researches have focused on the mechanisms of blast injuries within gascontaining organs/organ systems such as the lungs, while primary blast-induced traumatic brain injury has remained underestimated. Secondary injuries are due to bomb fragments, tertiary injuries are due to blast wind, and quaternary injuries include all other injuries ${ }^{4}$ Acil Servis, Siirt. 


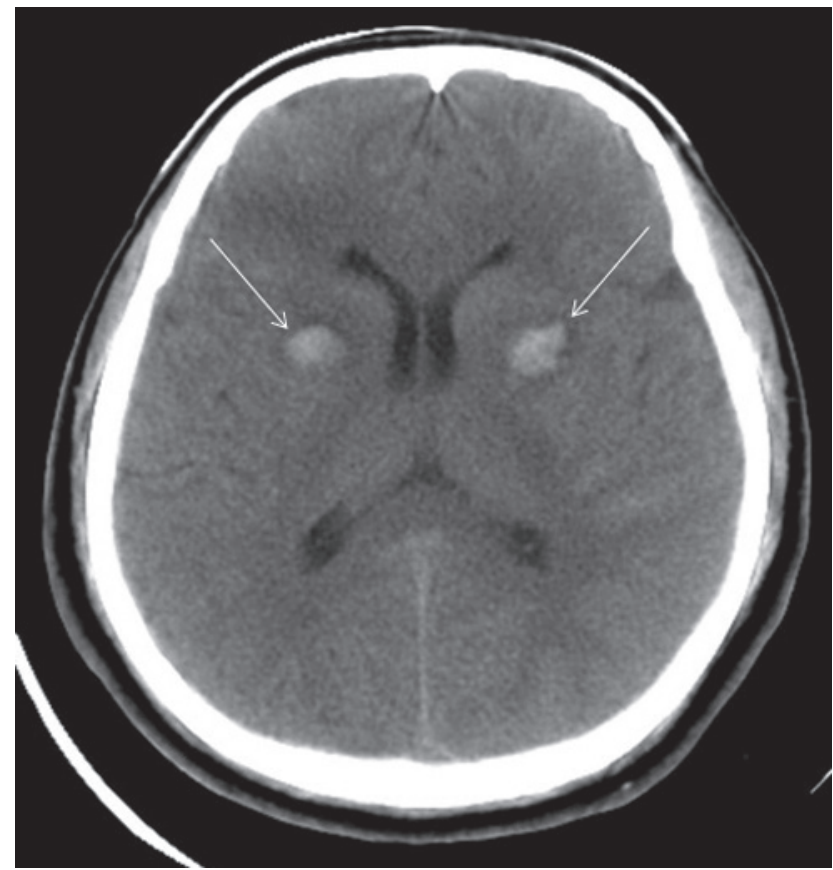

Fig. 1. Axial plane computed tomography shows bilateral basal ganglia hemorrhage (arrows) with mild edema.

not covered in the first three classes. ${ }^{[7]}$

To our best knowledge, there are a few articles about traumatic bilateral basal ganglia hemorrhage, but none about blast injury. ${ }^{[5,6]}$ The mechanism of traumatic basal ganglia hemorrhage has not been clear, but is believed to arise from a shear strain in the ganglionic region. Likewise, we could not determine the factors that led to the bilateral basal ganglia hemorrhage in our case. The high pressure of the blast injury (primary injury) or head trauma by blast wind (tertiary injury) can explain the etiology, but it is possible that the sudden-onset hypertension due to the adrenaline discharge caused the bilateral basal ganglia hemorrhage. This topic requires further investigations about blast injury to understand the actual mechanism of blast bilateral basal ganglia hemorrhage.

Computed tomography (CT) remains essential in blast trauma, as it shows injuries to the lung or other parenchymal organs. Likewise, cranial injury can be revealed with non-contrast cranial CT, and cranial examination should be performed in patients with blast injury. Bilateral basal ganglia hemorrhage must be documented as a complication of blast injury.

In conclusion, researches about bilateral basal ganglia hemorrhage are needed in order to understand the mechanism of hemorrhage secondary to blast injury.

\section{REFERENCES}

1. Weisberg LA, Stazio A, Elliott D, Shamsnia M. Putaminal hemorrhage: clinical-computed tomographic correlations. Neuroradiology 1990;32:200-6.

2. Ozgun B, Castillo M. Basal ganglia hemorrhage related to lightning strike. AJNR Am J Neuroradiol 1995;16:1370-1.

3. Cho SJ, Won TK, Hwang SJ, Kwon JH. Bilateral putaminal hemorrhage with cerebral edema in hyperglycemic hyperosmolar syndrome. Yonsei Med J 2002;43:533-5.

5. Renard D, Brunel H, Gaillard N. Bilateral haemorrhagic infarction of the globus pallidus after cocaine and alcohol intoxication. Acta Neurol Belg 2009;109:159-61.

6. Yanaka K, Egashira T, Maki Y, Takano S, Okazaki M, Matsumaru Y, et al. Bilateral traumatic hemorrhage in the basal ganglia: report of two cases. [Article in Japanese] No Shinkei Geka 1991;19:369-73. [Abstract]

7. Jang KJ, Jwa SC, Kim KH, Kang JK. Bilateral traumatic hemorrhage of the basal ganglia. J Korean Neurosurg Soc 2007;41:272-4 